\title{
Obituary: William L. Woolverton
}

\author{
Robert L. Balster • Michael A. Nader • Kevin B. Freeman
}

Received: 23 July 2013 / Accepted: 30 July 2013 /Published online: 16 August 2013

(C) Springer-Verlag Berlin Heidelberg 2013

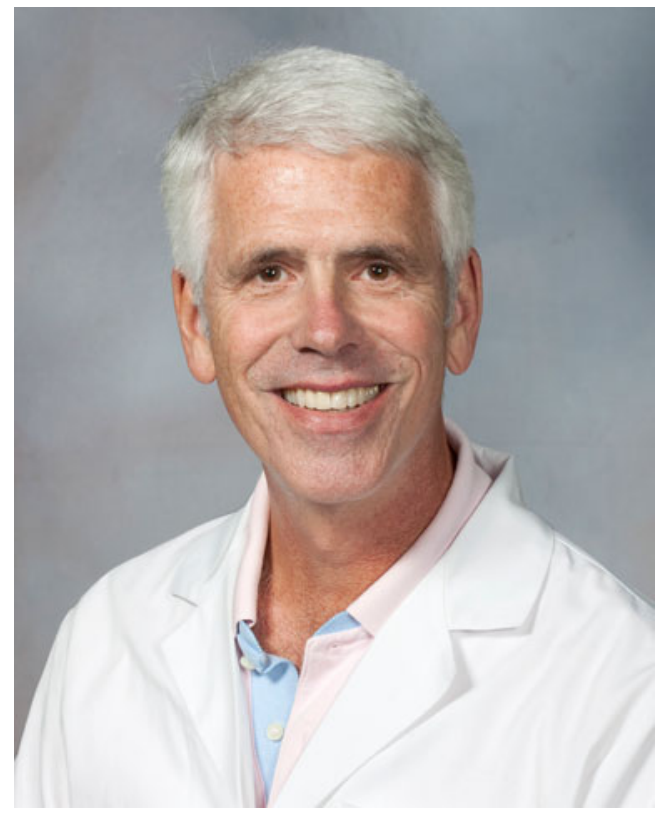

Dr. William L. Woolverton, Billy S. Guyton Distinguished Professor and Vice Chair for Research in the Department of Psychiatry and Human Behavior at the University of Mississippi Medical Center, died after a brief illness at the age of 62 on June 13, 2013. Prof. Woolverton was a leading scientist and educator in the behavioral pharmacology of drugs of abuse.

R. L. Balster $(\bowtie)$

Pharmacology and Toxicology, Virginia Commonwealth University, Richmond, USA

e-mail: balster@vcu.edu

\section{A. Nader}

Physiology and Pharmacology, Wake Forest University, Winston-Salem, USA

K. B. Freeman

Psychiatry and Human Behavior, University of Mississippi, Mississippi, USA
An Alabama native, Woolverton attended the University of the South in Sewanee, Tennessee, graduating Phi Beta Kappa in 1972. While at Sewanee, he did undergraduate behavioral pharmacology research with Dr. Ronald Trost, which led him to graduate school at the University of Chicago, studying pharmacology under the mentorship of Dr. Charles R. Schuster and graduating with a $\mathrm{PhD}$ in 1977. Although Woolverton received his formal training as a pharmacologist, he was strongly influenced by the behavioral sciences, conducting his doctoral research in the Psychiatry Department with a psychologist in a behavioral sciences research laboratory. Thus, many of Woolverton's major scientific contributions were on the behavioral determinants of the abuse-related effects of drugs. He did most of his research in nonhuman primate laboratories. His predoctoral research was on tolerance to the effects of stimulants.

Upon graduation, Woolverton was recruited to the Virginia Commonwealth University Drug Abuse Training Program where he was supported under a National Institute on Drug Abuse training grant and individual post-doctoral fellowship for the period of 1977-1980. He did his post-doctoral training primarily in the laboratories of Dr. Robert Balster in the Department of Pharmacology and Toxicology headed by Dr. Louis Harris. This was an enormously productive period as he co-authored 18 scientific journal publications based on those 3 years of work. Woolverton wanted to understand better how the reinforcing effects of drugs were altered by the context of their availability. This led him to a series of complex choice studies in which rhesus monkeys were given opportunities to select cocaine or food reinforcement and how various manipulations, such as concurrent drug treatment, altered this choice behavior (e.g., Woolverton and Balster 1981). The results of this line of work convinced Woolverton that drug taking behavior was not "impulsive" and "out of control" as has often been proposed, but rather, is directly determined by the context of its availability, providing a nuanced understanding of drug-behavior interactions. In addition to this line of work, Woolverton also completed some important basic work on the 
abuse-related properties of phencyclidine-like drugs as well as other research.

In 1980, Woolverton returned to the University of Chicago as a Research Associate (Assistant Professor) in the Department of Psychiatry in the research group headed by Charles R. Schuster. During the early years back in Chicago, he was surrounded by like-minded behavioral pharmacologists Chris-Ellyn Johanson, Lewis Seiden, Harriett deWit, Larry Chait, Mark Kleven, and Kathleen Grant. When Schuster left the University of Chicago to become Director of the National Institute on Drug Abuse in 1986, Woolverton replaced him as the Director of the Drug Abuse Research Center. This, too, was an extremely productive time in Woolverton's career. Woolverton played a key role overseeing several projects which led to some of his most significant findings related to the role of dopamine in cocaine abuse. For example, Woolverton, Goldberg, and Ginos (1984) examined the reinforcing effects of several dopamine receptor agonists. At the time of this study, D1 and D2 receptor subtypes had only recently been proposed and their functional roles were unknown. Woolverton showed that only agonists at $\mathrm{D} 2$ receptor subtypes functioned as reinforcers. Woolverton followed this study by examining D1- and D2-like receptor antagonists on the reinforcing and discriminative stimulus effects of cocaine. While D1-like agonists would not function as reinforcers (he would later amend this conclusion by testing higher efficacy D1 agonists), D1-like antagonists blocked cocaine selfadministration indicating an important role for this receptor subtype in cocaine reinforcement. Woolverton extended his initial findings with receptor antagonists by showing that these effects were not selective for cocaine by using a multiple schedule in which responses by monkeys were also maintained by food reinforcement. Much of his research focused on the pharmacology of cocaine using novel drugs developed by chemistry colleagues.

While in Chicago, Woolverton continued his development of homologous animal models of drug addiction. For example, Woolverton and Kleven (1988) reported withdrawal symptoms following high doses of cocaine in monkeys. He also continued his studies with drug choice paradigms. To determine the reinforcing efficacy of cathinone, an alkaloid of the Khat plant that has amphetamine-like effects, Woolverton and Johanson (1984) gave monkeys the opportunity to choose between cocaine and cathinone and found that cathinone was equally reinforcing to cocaine. This work led Woolverton to a long series of studies that focused on models of reinforcing strength including the systematic evaluation of progressive-ratio parameters (e.g., Woolverton 1995) and food-drug choice studies. These latter studies included the evaluation of environmental manipulations in studies with Michael Nader, examining changes in the magnitude of alternative reinforcers and the response requirement for each reinforcer (e.g., Nader and Woolverton 1991).
The Chicago years also included bi-annual retreats with James Woods and his laboratory at the University of Michigan, which featured young scientists presenting their research findings in front of an impressively intimidating audience. While at Chicago, Bill's zest for life included owning a Porsche, learning to fly airplanes, and a keen interest in Alfred Hitchcock movies. Woolverton remained in Chicago until 1993. During that nearly decade and a half, he trained 15 students and post-doctoral fellows. He also met and married his wife, Candy, while in Chicago.

In 1993, Woolverton was recruited to the University of Mississippi Medical Center (UMMC) at the rank of professor and served as Vice Chair for Research in the Department of Psychiatry and Human Behavior until his passing. During his time at UMMC, Woolverton provided critical leadership for the inception and development of a number of programs that have had a lasting impact on the institution. In 1994, he became the first director of the Division of Neurobiology and Behavior Research. He also served as the chair of the steering committee for the Program in Neuroscience, an interdepartmental graduate program offering a doctoral degree in Neuroscience. Woolverton trained a number of researchers while at UMMC, including Drs. James Rowlett, Michael Weed, Kristin Wilcox, Karen Anderson, Sunmee Wee, Kevin Freeman, and Sally Huskinson. In 2010, Woolverton was awarded the Billy S. Guyton Distinguished Professorship, the highest honor that is bestowed upon researchers at UMMC. He was held in the highest regard by the faculty and staff with whom he interacted, and his wisdom, which he shared selflessly and with humility, will continue to shape the academic environment at UMMC for years to come because so many have fashioned their professional behavior after his example.

The scope of Woolverton's research during his years at UMMC included further work on the reinforcing effects of direct and indirect monoamine agonists, the behavioral pharmacology of benzodiazepines, the application of behavioral economics to the measurement of drug reinforcement, and the investigation of drug interactions as determinants of polydrug abuse. However, Woolverton's long-standing interest in how environmental circumstances shape the choice to take drugs gave rise to some of his most innovative work at UMMC. He investigated the effects of probability of and delay to reinforcement on the choice to self-administer cocaine when nondrug alternatives were available. In 2007, he began a longstanding and productive collaboration with two experts in delay discounting, Drs. Leonard Green and Joel Myerson, which resulted in the first paper to demonstrate hyperbolic discounting of delayed drug injections (Woolverton et al. 2007). He followed this study with others examining delay discounting of non-drug reinforcers in monkeys and found that monkeys discounted delayed drug injections less steeply than non-drug reinforcers (Freeman et al. 2012). Woolverton 
also introduced the use of choice procedures to study drugs as punishers (Woolverton 2003). In 2012, he reported hyperbolic discounting of delayed punishment with histamine in monkeys self-administering cocaine injections, which was the first study to examine the effects of delaying punishment on drug self-administration (Woolverton et al. 2012). This body of work was ongoing at the time of Woolverton's death, as were his ideas on how it should be developed. Thus, with peaking creativity and no twilight in sight, Woolverton pushed the envelope of behavioral pharmacology until the end.

Dr. Woolverton was very active in the College on Problems of Drug Dependence, serving on the Board of Directors from 1997 to 2001. He also served as Secretary and the President of the International Study Group Investigating Drugs as Reinforcers and President of the Society for the Stimulus Properties of Drugs. Reflecting his contributions to behavioral sciences research, Woolverton was a Fellow of the American Psychological Association.

Woolverton was much admired by his colleagues and students. He had a very inquisitive mind and liked to challenge accepted scientific beliefs. He had a gentle way of guiding the development of his trainees and in engaging his research peers in the field. He loved to play and sing in the ever-shifting band of friends and colleagues that he cultivated primarily during his Mississippi years. He will be greatly missed. He is survived by his wife Candy Woolverton, and his son Chris and daughter Lucy. Among his last wishes before he died, Woolverton characteristically wanted the memorial service to be a "celebration," with the music he loved and poetry by WB Yeats. His wishes were honored.
Conflicts of interest The authors declare that they have no conflicts of interest.

\section{References}

Freeman KB, Nonemacher J, Green L, Myerson J, Woolverton WL (2012) Delay discounting in rhesus monkeys: equivalent discounting of more and less preferred sucrose concentrations. Learn Behav 40:54-60

Nader MA, Woolverton WL (1991) Effects of increasing the magnitude of an alternative reinforcer on drug choice in a discrete-trials choice procedure. Psychopharmacology 105:169-174

Woolverton WL (1995) Comparison of the reinforcing efficacy of cocaine and procaine in rhesus monkeys responding under a progressive-ratio schedule. Psychopharmacology 120:296-302

Woolverton WL (2003) A novel choice method for studying drugs as punishers. Pharmacol, Biochem Behav 76:125-131

Woolverton WL, Balster RL (1981) The effects of antipsychotic compounds in rhesus monkeys given a choice between cocaine and food. Drug Alc Depend 8:69-78

Woolverton WL, Freeman KB, Myerson J, Green L (2012) Suppression of cocaine self-administration in monkeys: effects of delayed punishment. Psychopharmacology 220:509-517

Woolverton WL, Goldberg LI, Ginos JZ (1984) Intravenous selfadministration of dopamine receptor agonists by rhesus monkeys. J Pharmacol Exp Ther 230:678-683

Woolverton WL, Johanson CE (1984) Preference in rhesus monkeys given a choice between cocaine and d,1-cathinone. J Exp Analysis Behav 41:35-43

Woolverton WL, Kleven MS (1988) Evidence for cocaine dependence in monkeys following a prolonged period of exposure. Psychopharmacology 94:288-291

Woolverton WL, Myerson J, Green L (2007) Delay discounting of cocaine by rhesus monkeys. Exp Clin Psychopharmacol 15:238-244 